\title{
Analysis of the July 10th 2013 Tectonic Earthquake effect on the Coordinates Changes of Mentawai Segment Monitoring Station
}

\author{
Hilmiyati Ulinnuha, Aris Sunantyo, Nurrohmat Widjajanti \\ Department of Geodetic Engineering, Universitas Gadjah Mada, Yogyakarta, INDONESIA
}

\section{Article History:}

Received 3 October 2018

Received in revised form 4 December 2018

Accepted 14 December 2018

Available online 31 January 2019

\section{Keywords:}

Earthquake, Mentawai, Subduction, SuGAr.

Corresponding Author:

Hilmiyati Ulinnuha

Email: ulinnuhahilmiyati@gmail.com

\begin{abstract}
Mentawai Segment is located in Mentawai Islands, Sumatra, Indonesia. This segment is a subduction zone between Indo-Australian plate and Eurasian plate. This subduction zone can lead to high potential of tectonic earthquake in Mentawai Segment. The high potential of tectonic earthquake has negative impact for the community, so it is necessary to monitor the risk of tectonic earthquake in Mentawai Segment. This monitoring can be done by using GPS data of monitoring station that spread in Mentawai Segment. Therefore, this research aims to analyze the effect of tectonic earthquake on the coordinate change of Mentawai Segment. This research use observation data of 10 continuous GPS monitoring station (Sumatran GPS Data Array / SuGAr) in Mentawai Segment. Day of observation data was day of year (doy) at the time of tectonic earthquake occurence on July 10, 2013. Data processing used scientific data processing software. The results of this research indicate that the tectonic earthquake (July 10, 2013) affected coordinates changes of the SuGAr station significantly two hours after the tectonic earthquake occurred.
\end{abstract}

(C) Author(s) 2018. This is an open access article under the Creative Commons Attribution-ShareAlike 4.0 International License (CC BY-SA 4.0).

\section{Pendahuluan}

Zona subduksi di Pulau Sumatera merupakan pertemuan lempeng tektonik yang paling sering melepaskan energi (Setyonegoro, dkk., 2012). Segmen Mentawai merupakan zona subduksi lempeng tektonik yang terletak di Kepulauan Mentawai. Kepulauan ini terletak di bagian barat Sumatera. Pada tanggal 10 Juli 2013 terjadi gempa bumi berturut-turut dengan kekuatan 5,2 SR dan 5,3 SR. Gempa bumi ini disebabkan oleh aktivitas sesar naik Segmen Mentawai.

Berdasarkan penelitian Bock dan Prawirodirdjo (2003), total energi yang dilepaskan sepanjang Segmen Mentawai sampai tahun 2007 tidak lebih dari sepertiga energi yang terlepas dari total energi yang sudah terkumpul sejak gempa bumi tahun 1797 dan 1833. Oleh karena itu, gempa bumi tektonik dapat terus terulang di Segmen Mentawai. Perulangan gemba bumi tektonik disebut earthquake cycle (Sarsito, dkk., 2005).

Hingga saat ini, Kepulauan Mentawai masih sering dilanda gempa tektonik. Pada tanggal 5 Agustus 2018, telah terjadi gempa tektonik dengan kekuatan 5,2 SR. Gempa tektonik ini terletak di area laut pada kedalaman
$31 \mathrm{~km}$, berjarak $41 \mathrm{~km}$ arah barat daya dari Kota Tua Pejat, Kepulauan Mentawai. Kejadian ini mendukung hasil penelitian Bock dan Prawirodirdjo (2003) mengenai tingginya resiko perulangan gempa tektonik.

Hasil penelitian Fidia dkk (2018) juga menunjukkan bahwa Kepulauan Mentawai memiliki tingkat keaktifan yang tinggi dengan periode pengulangan 0,4633 s.d. 150,5033 tahun pada gempa dengan magnitudo 5 s.d. 8 SR. Resiko perulangan gempa bumi tektonik di Segmen Mentawai memerlukan pemantauan secara berkala. Salah satu metode yang dapat digunakan dalam pemantauan gempa bumi yang disebabkan oleh aktivitas tektonik adalah dengan pengamatan posisi suatu titik pantau. Pengamatan posisi ini dapat dilakukan dengan menggunakan teknologi GNSS. Pulau Sumatera terdapat stasiun-stasiun GPS yang melakukan pengukuran geodetik secara kontinyu. Stasiun ini dikenal dengan stasiun SuGAr (Sumatran GPS Data Array).

Pengamatan posisi dengan GNSS dapat memberikan gambaran pergerakan posisi titik pantau Segmen Mentawai secara kontinyu. Oleh karena itu, metode pengamatan posisi ini dapat menggambarkan kondisi titik pantau selama satu fase gempa tektonik (earthquake cycle). 
Satu earthquake cycle memiliki beberapa fase gempa bumi yaitu interseismic, pre-seismic, coseismic, dan post-seismic. Satu cycle gempa bumi ini dapat berlangsung dalam kurun waktu seratus tahun (Sarsito, dkk., 2005).

Fase interseismic merupakan fase ketika energi dari dalam bumi menggerakkan lempeng dan energi tersebut mulai terakumulasi di bagian batas antar lempeng dan patahan. Fase interseismic merupakan fase awal dari earthquake cycle dan terjadi sebelum fase coseismic. Sedangkan Fase pre-seismic terjadi ketika sesaat sebelum gempa tektonik terjadi (Sarsito, dkk., 2005).

Fase coseismic merupakan fase ketika gempa bumi terjadi. Pada fase ini getaran pada bumi dirasakan paling kuat seiring terjadinya pelepasan energi secara tiba-tiba. Penelitian mengenai fase coseismic gempa bumi tektonik telah banyak dilakukan. Salah satunya adalah penelitian Hongbo dkk (2013). Penelitan tersebut bertujuan untuk mengetahui besar deformasi gempa bumi Lushan yang memiliki kekuatan 7,0 SR. Gempa bumi ini terjadi setelah gempa 3,0 SR, 5 SR, dan 5,4 SR. Hasil penelitian tersebut menunjukkan bahwa fase coseismic gempa bumi Lushan mengakibatkan deformasi horizontal kurang dari $10 \mathrm{~mm}$ dan deformasi vertikal kurang dari $5 \mathrm{~mm}$.

Selain penelitian fase coseismic pada gempa bumi, penelitian mengenai gempa di Pulau Sumatera juga telah banyak dilakukan. Diantaranya adalah penelitian Prawirodirdjo (2010), Sugiyanto dkk (2011) dan Permana (2012). Penelitian yang dilakukan oleh Prawirodirdjo (2010) bertujuan untuk menganalisis segmentasi patahan siklus gempa bumi pada megathrust Sumatera, yang terjadi pada 26 Desember $2004 \mathrm{Mw} 9.1$ Andaman, 28 Maret 2005 Mw 8.7 Nias, dan 12 September 2007 Mw 8.4 gempa Mentawai menggunakan data pengamatan stasiun SuGAr (Sumatran GPS Data Array). Hasil penelitian Prawirodijdjo (2010) adalah megathrust Sumatra atau Sesar Sumatera mengalami segmentasi, sebuah karakteristik yang dapat terus bertahan selama beberapa siklus gempa.

Penelitian deformasi permukaan patahan aktif Seulimum dan Segmen Aceh yang dilakukan oleh Sugiyanto dkk (2010) menggunakan data pengamatan GPS yang diikatkan ke stasiun CORS yang berada di Sampali dan Aceh. Tujuan dari penelitian tersebut adalah melakukan pemutakhiran data perubahan koordinat pada jaringan pengamatan GPS wilayah Aceh, mempelajari karakteristik patahan aktif segmen Aceh dan segmen Seulimum, serta menghitung besar pergeseran postseismic yang terjadi setelah gempa Aceh 2004. Hasil dari penelitian tersebut menunjukkan bahwa wilayah Aceh masih dipengaruhi oleh aktivitas post-seismic gempa Aceh 2004 dengan rata-rata besar pergeserannya adalah 10 $\mathrm{mm} /$ tahun.

Analisis deformasi Pulau Sumatera juga dilakukan oleh Permana (2012). Penelitian tersebut bertujuan untuk mengetahui dampak gempa Padang 2009 terhadap 28 stasiun SuGAr dan mengitung besar regangan yang ditimbulkan. Hasil penelitian tersebut menunjukkan bahwa kecepatan titik-titik yang berada di sepanjang kepulauan Mentawai adalah $2 \mathrm{~cm} /$ tahun, dan $1 \mathrm{~cm} /$ tahun untuk titik-titik yang berada di sepanjang pantai barat Pulau Sumatera. Vektor pergeseran titik-titik pengamatan GPS tersebut cenderung bergerak ke arah timurlaut dan baratdaya. Vektor pergeseran ke arah timurlaut mengindikasikan adanya akumulasi energi, sedangkan vektor pergeseran yang mengarah ke baratdaya mengindikasikan adanya pelepasan energi.

Meskipun telah banyak penelitian mengenai gempa bumi di Pulau Sumatera, namun belum ada yang membahas mengenai pengaruh gempa bumi tektonik terhadap perubahan koordinat titik pantau ketika fase coseismic. Oleh karena itu, penelitian ini bertujuan untuk menganalisis pengaruh gempa bumi tektonik 10 Juli 2013 dengan kekuatan 5,2 dan 5,3 SR terhadap perubahan posisi stasiun SuGAr di Segmen Mentawai pada fase coseismic.

\section{Data dan Metodologi}

Bagian ini menjelaskan Penelitian ini menggunakan data pengamatan GPS stasiun SuGAr berjumlah 10 stasiun yang tersebar di Segmen Mentawai, yaitu stasiun BSAT, BTET, SMGY, TLLU, KTET, TIKU, LNNG, PSKI, TRTK dan MKMK. Zona subduksi Segmen Mentawai dan stasiun SuGAr yang digunakan ditunjukkan pada Gambar 2.1.

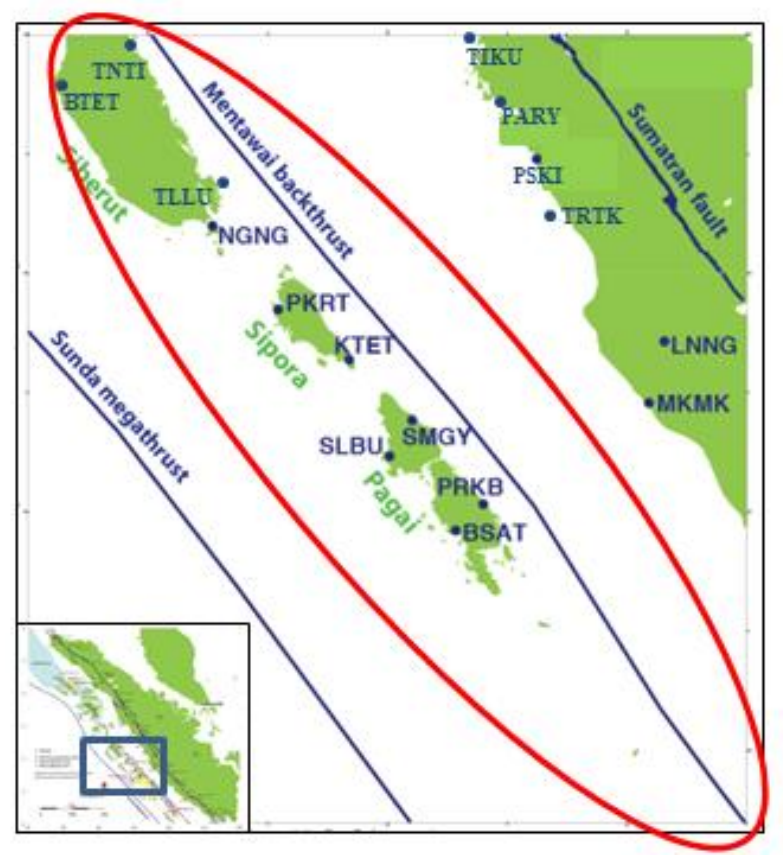

Gambar 2.1 Zona Subduksi Segmen Mentawai dan 10 stasiun SuGAr (modifikasi dari EOS, 2012)

Berdasarkan Gambar 2.1, Kepulauan Mentawai terdiri dari tiga pulau utama yaitu Siberut, Sipora, dan Pagai. 
Zona subduksi Segmen Mentawai terletak di sebelah timurlaut dari ketiga Pulau tersebut. Pada penelitian ini, stasiun SuGAr yang digunakan 5 stasiun berada di sebelah timurlaut zona subduksi Segmen Mentawai, dan 5 stasiun terletak di sebelah baratdaya zona subduksi Segmen Mentawai.

Tahap penelitian ini terdiri dari persiapan, pengumpulan data pengamatan, pengolahan data, dan analisis hasil pengolahan data pengamatan. Tahap-tahap penelitian dijabarkan sebagai berikut :

\subsection{Persiapan}

Tahap persiapan merupakan tahapan awal dari penelitian ini. Pada tahap ini dilakukan persiapan perangkat lunak scientific yang digunakan untuk pengolahan data pengamatan GPS. Selain persiapan perangkat lunak, juga dilakukan peninjauan pustaka dan hasil penelitian sebelumnya.

\subsection{Pengumpulan data pengamatan}

Pada tahap ini dilakukan pengumpulan data pengamatan 10 stasiun SuGAr yang telah ditentukan. Data yang digunakan sebagai data pengamatan fase coseismic adalah data pengamatan 10 stasiun SuGAr pada hari gempa tektonik 10 Juli 2013. Day of Year (DOY) yang digunakan adalah DOY 191.

\subsection{Pengolahan data pegamatan}

Pada tahap ini dilakukan pengolahan data pengamatan 10 stasiun SuGAr pada DOY 191 dengan pembagian data terlebih dahulu. Pembagian data terdiri dari satu jam sebelum gempa, satu jam setelah gempa, dua jam setelah gempa, dan satu hari setelah gempa. Selanjutnya, data pengamatan diolah dengan skema data satu jam sebelum gempa, satu jam setelah gempa, dua jam setelah gempa, dan satu hari setelah gempa.

\subsection{Analisis hasil pengolahan data pengamatan}

Analisis hasil pengolahan data pengamatan dimulai dari analisis pengolahan data pengamatan menggunakan perangkat lunak scientific yang menghasilkan nilai fract dan postfit nrms. Analisis hasil pengolahan data menggunakan kriteria nilai fract $<10$ dan nilai postfit $\mathrm{nrms}$ $<0,25$. Hal ini mengindikasikan tidak adanya kesalahan kasar dan tidak adanya efek cycle slip yang belum dihilangkan berkaitan dengan parameter bias ekstra atau terdapat kesalahan dalam pemodelan.

Hasil pengolahan data berupa koordinat dan simpangan baku koordinat 10 stasiun SuGAr pada fase coseismic. Koordinat masing-masing pengolahan kemudian dilakukan uji signifikansi beda dua parameter untuk melihat signifikansi perubahan koordinat. Uji signifikansi dilakukan untuk menganalisis perbedaan koordinat fase coseismic dengan koordinat fase interseismic gempa tektonik 10 Juli 2013. Uji signifikansi yang dilakukan yaitu uji signifikansi perubahan koordinat stasiun SuGAr pada fase interseismic dengan koordinat stasiun SuGAr satu jam sebelum gempa, satu jam setelah gempa, dua jam setelah gempa dan satu hari setelah gempa. Perbedaan koordinat yang signifikan menunjukkan adanya pengaruh gempa tektonik 10 Juli 2013. Koordinat dan simpangan baku 10 stasiun SuGAr pada fase interseismic ditunjukkan pada Tabel 2.1 dan Tabel 2.2.

Tabel 2.1 Koordinat stasiun SuGAr pada fase interseismic gempa tektonik 10 Juli 2013

\begin{tabular}{llcl}
\hline Stasiun & \multicolumn{1}{c}{$\mathbf{X}(\mathbf{m})$} & $\mathbf{Y}(\mathbf{m})$ & \multicolumn{1}{c}{$\mathbf{Z}(\mathbf{m})$} \\
\hline BSAT & $-1137103,527$ & 6266681,548 & $-340044,539$ \\
BTET & $-958358,345$ & 6304144,429 & $-141694,186$ \\
SMGY & $-1117646,075$ & 6272758,474 & $-288996,298$ \\
TLLU & $-1012024,751$ & 6294267,002 & $-199040,113$ \\
KTET & $-1089170,731$ & 6279021,694 & $-261166,053$ \\
TIKU & $-1101409,098$ & 6282181,345 & $-44132,832$ \\
LNNG & $-1233134,180$ & 6252700,391 & $-252634,261$ \\
PSKI & $-1146062,884$ & 6273134,042 & $-124354,052$ \\
TRTK & $-1175522,349$ & 6266728,961 & $-168139,831$ \\
MKMK & $-1225793,317$ & 6252881,913 & $-281063,925$ \\
\hline
\end{tabular}

Sumber. (Ulinnuha, 2015)

Tabel 2.2 Simpangan baku Koordinat stasiun SuGAr pada fase interseismic gempa tektonik 10 Juli 2013

\begin{tabular}{lccc}
\hline Stasiun & $\boldsymbol{\sigma} \mathbf{X}(\mathbf{m m})$ & $\boldsymbol{\sigma} \mathbf{Y}(\mathbf{m m})$ & $\boldsymbol{\sigma Z}(\mathbf{m m})$ \\
\hline BSAT & 0,79 & 2,2 & 0,48 \\
BTET & 0,71 & 1,82 & 0,45 \\
SMGY & 0,79 & 2,07 & 0,5 \\
TLLU & 0,7 & 1,72 & 0,44 \\
KTET & 1 & 2,75 & 0,66 \\
TIKU & 0,77 & 1,93 & 0,47 \\
LNNG & 0,72 & 1,74 & 0,42 \\
PSKI & 0,74 & 1,85 & 0,46 \\
TRTK & 0,63 & 1,44 & 0,4 \\
MKMK & 0,66 & 1,56 & 0,41 \\
\hline
\end{tabular}

Sumber. (Ulinnuha, 2015)

Uji signifikansi beda dua parameter dilakukan sesuai dengan persamaan (1) dan (2). Uji ini menggunakan distribusi Student dengan tingkat kepercayaan 95\%, dan derajat kebebasan $=\infty$, maka didapatkan nilai $t=1,96$. Penolakan hipotesis nol $\left(\mathrm{H}_{\mathrm{o}}\right)$ apabila kriteria tidak sesuai dengan persamaan (2). Penolakan hipotesis nol menunjukkan bahwa koordinat berbeda secara signifikan. 


$$
\begin{aligned}
& \mathrm{t}=\frac{\left[X_{1}-X_{2}\right]}{\sqrt{\sigma_{x 1}^{2}+\sigma_{x 2}^{2}}} \\
& \mathrm{t} \leq \mathrm{t}_{(\alpha / 2, \mathrm{df})}
\end{aligned}
$$

\section{Hasil dan Pembahasan}

Hasil penelitian ini dibagi dalam hasil pengolahan data pengamatan menggunakan perangkat lunak scientific dan hasil uji signifikansi beda dua parameter.

\subsection{Hasil analisis nilai fract dan postfit $n r m s$}

Hasil pengolahan data pada penelitian ini berupa solusi bias fixed dan solusi bias free. Solusi ini dalam file*.glx dan *.glr. Untuk mengevaluasi hasil pengolahan dilakukan dengan melihat nilai fract dan postfit nrms yang dihasilkan. Nilai fract dan postfit nrms yang dihasilkan dalam penelitian ini ditunjukkan pada Tabel 3.1.

Tabel 3.1 Nilai fract hasil pengolahan data pengamatan

\begin{tabular}{lcc}
\hline \multicolumn{1}{c}{ Projek } & $\begin{array}{l}\text { Nilai fract } \\
\text { terbesar }\end{array}$ & $\begin{array}{l}\text { Nilai fract } \\
\text { terkecil }\end{array}$ \\
\hline $\begin{array}{l}\text { Satu jam sebelum } \\
\text { gempa }\end{array}$ & 1,1 & $-0,6$ \\
$\begin{array}{l}\text { Satu jam setelah } \\
\text { gempa }\end{array}$ & 0,8 & $-2,2$ \\
$\begin{array}{l}\text { Dua jam setelah } \\
\text { gempa }\end{array}$ & 3,4 & $-5,2$ \\
$\begin{array}{l}\text { Satu hari setelah } \\
\text { gempa }\end{array}$ & 2 & $-2,1$ \\
\hline
\end{tabular}

Berdasarkan Tabel 3.1. Nilai fract hasil pengolahan data pengamatan memiliki nilai kurang dari 10 . Nilai fract terbesar yang dihasilkan adalah 3,4, sehingga nilai fract pada semua projek pengolahan data fase coseismic telah memenuhi kriteria nilai fract.

Tabel 3.2 Nilai postfit nrms hasil pengolahan data pengamatan

\begin{tabular}{ll}
\hline Projek & Nilai postfit nrms \\
\hline Satu jam sebelum gempa & 0,2047 \\
Satu jam setelah gempa & 0,2154 \\
Dua jam setelah gempa & 0,1976 \\
Satu hari setelah gempa & 0,1835 \\
\hline
\end{tabular}

Tabel 3.2 menunjukkan nilai postfit nrms hasil pengolahan data pengamatan pada fase coseismic. Nilai postfit nrms sesuai Tabel 3.2 memiliki nilai antara 1,835 sampai dengan 0,2154. Nilai postfit nrms paling kecil terdapat pada pengolahan data pengamatan satu hari setelah gempa, dan nilai postfit nrms terbesar pada pengolahan data pengamatan satu jam setelah gempa.
Nilai postfit nrms pada semua pengolahan data fase coseismic memiliki nilai kurang dari 0,25 , sehingga semua hasil pengamatan telah memenuhi kriteria nilai postfit nrms.

3.2. Hasil analisis nilai wrms, $n r m s$, dan koordinat

Hasil pengolahan GLOBK dievaluasi dengan nilai wrms dan nrmsnya. Nilai wrms dan nrms hasil pengolahan data pengamatan fase coseismic ditunjukkan pada Gambar 3.1.

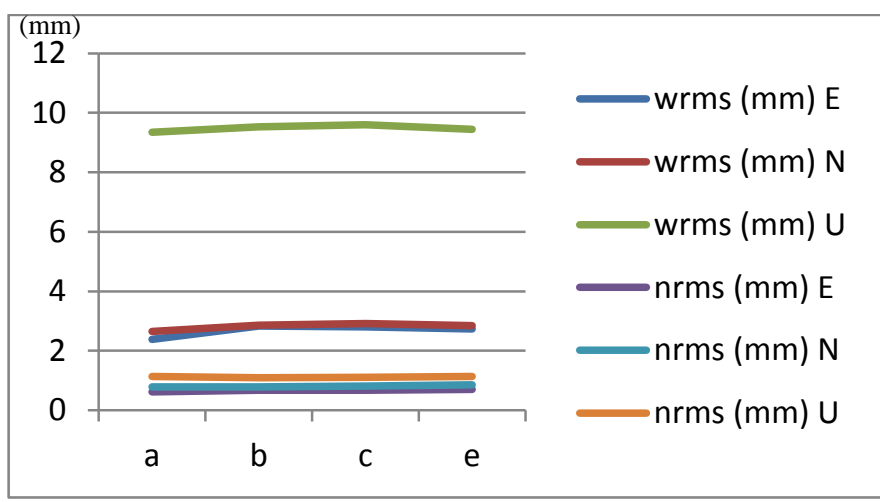

Gambar 3.1 Grafik nilai wrms dan nrms hasil pengolahan data pengamatan

Berdasarkan Gambar 3.1, nilai a menunjukkan hasil pengolahan satu jam sebelum gempa, nilai b menunjukkan hasil pengolahan satu jam setelah gempa, nilai c menunjukkan hasil pengolahan dua jam setelah gempa, dan nilai e menunjukkan hasil pengolahan satu hari setelah gempa. Nilai wrms dan nrms untuk semua hasil pengolahan memiliki nilai kurang dari $4 \mathrm{~mm}$ pada kompenen E dan komponen N. Sedangkan kompenen U memiliki nilai dibawah $2 \mathrm{~mm}$ untuk $\mathrm{nrms}$, sedangkan nilai wrms memiliki nilai antara $8 \mathrm{~mm}$ s.d 9,6 mm.

Tabel 3.3 Koordinat dan simpangan baku hasil pengolahan data satu hari setelah gempa

\begin{tabular}{cccc}
\hline Stasiun & $\mathbf{X}(\mathbf{m})$ & $\mathbf{Y}(\mathbf{m})$ & $\mathbf{Z}(\mathbf{m})$ \\
\hline BSAT & $-1137103,51326$ & 6266681,54868 & $-340044,55014$ \\
BTET & $-958358,35169$ & 6304144,42887 & $-141694,17743$ \\
SMGY & $-1117646,07084$ & 6272758,48378 & $-288996,29916$ \\
TLLU & $-1012024,75494$ & 6294267,00268 & $-199040,10452$ \\
KTET & $-1089170,73264$ & 6279021,68212 & $-261166,06732$ \\
TIKU & $-1101409,10523$ & 6282181,36047 & $-44132,83142$ \\
LNNG & $-1233134,17866$ & 6252700,39325 & $-252634,26480$ \\
PSKI & $-1146062,88040$ & 6273134,04711 & $-124354,05493$ \\
TRTK & $-1175522,35217$ & 6266728,96841 & $-168139,83241$ \\
MKMK & $-1225793,31595$ & 6252881,92214 & $-281063,92814$ \\
\hline
\end{tabular}


Tabel 3.4 Simpangan baku hasil pengolahan data satu hari setelah gempa

\begin{tabular}{clll}
\hline Stasiun & $\boldsymbol{\sigma X}(\mathbf{c m})$ & $\boldsymbol{\sigma} \mathbf{Y}(\mathbf{c m})$ & $\boldsymbol{\sigma Z}(\mathbf{c m})$ \\
\hline BSAT & 0,415 & 1,021 & 0,257 \\
BTET & 0,378 & 0,885 & 0,249 \\
SMGY & 0,544 & 1,439 & 0,345 \\
TLLU & 0,361 & 0,783 & 0,238 \\
KTET & 0,556 & 1,557 & 0,381 \\
TIKU & 0,375 & 0,85 & 0,237 \\
LNNG & 0,406 & 0,934 & 0,248 \\
PSKI & 0,385 & 0,892 & 0,249 \\
TRTK & 0,364 & 0,809 & 0,249 \\
MKMK & 0,347 & 0,708 & 0,223 \\
\hline
\end{tabular}

Tabel 3.3 dan Tabel 3.4 menunjukkan nilai koordinat kartesi 3D dan simpangan baku 10 stasiun SuGAr hasil pengolahan data pengamatan 1 hari setelah gempa tektonik (DOY 191). Nilai simpangan baku paling besar pada komponen Y atau komponen vertikal. Simpangan baku terbesar berada pada fraksi centimeter yaitu 1,557 $\mathrm{cm}$. Simpangan baku pada fraksi centimeter terdapat pada stasiun BSAT, SMGY, dan KTET.

Komponen vertikal atau komponen $\mathrm{Y}$ memiliki nilai simpangan baku yang lebih besar dari pada komponen horizontal yaitu komponen X dan komponen Z. Hal ini dapat disebabkan oleh faktor geometri satelit GPS yang tidak memungkinkan untuk mengamati satelit yang terletak dibawah horison, sehingga kekuatan jaring untuk komponen vertikal menjadi lebih lemah jika dibandingkan dengan kekuatan jaring horisontal.

\subsection{Hasil analisis signifikansi perbedaan koordinat}

Uji signifikansi beda parameter dilakukan untuk mengetahui signifikansi perbedaan koordinat 10 stasiun SuGAr pada fase interseismic dengan koordinat hasil pengolahan satu jam sebelum gempa, satu jam setelah gempa, dua jam setelah gempa, dan satu hari setelah gempa. Hasil uji signifikansi beda dua parameter pada uji signifikansi perubahan koordinat 10 stasiun SuGAr pada fase interseismic dengan koordinat hasil pengolahan satu jam sebelum gempa menunjukkan adanya penerimaan $\mathrm{H}_{0}$ pada semua stasiun SuGAr. Penerimaan $\mathrm{H}_{0}$ ini menunjukkan bahwa koordinat 10 stasiun SuGAr pada fase interseismic dan satu jam sebelum gempa tidak berbeda secara signifikan.

Hasil uji signifikansi beda dua parameter pada koordinat 10 stasiun SuGAr fase interseismic dan satu jam setelah gempa tektonik 10 Juli 2013 menunjukkan adanya penerimaan $\mathrm{H}_{\mathrm{o}}$ pada semua stasiun SuGAr. Penerimaan $\mathrm{H}_{\mathrm{o}}$ ini juga menunjukkan koordinat 10 stasiun SuGAr pada fase interseismic dan satu jam setelah gempa tidak berbeda secara signifikan.
Hasil uji signifikansi beda dua parameter untuk koordinat fase interseismic dan dua jam setelah gempa menunjukkan adanya penolakan $\mathrm{H}_{\mathrm{o}}$ pada komponen $\mathrm{Z}$ stasiun BTET. Stasiun BTET pada komponen Z memiliki nilai t-hitungan lebih dari 1,96. Penolakan ini menunjukkan adanya perubahan yang signifikan pada komponen Z stasiun BTET setelah dua jam gempa tektonik 10 Juli 2013 terjadi. Stasiun BTET pada komponen X dan komponen $\mathrm{Y}$ mengalami penerimaan $\mathrm{H}_{\mathrm{o}}$. Hal ini menunjukkan tidak ada perubahan koordinat yang signifikan. Sedangkan untuk stasiun yang lain, hasil uji signifikansi menunjukkan semua komponen koordinat tidak berbeda secara signifikan. Perbedaan koordinat yang signifikan pada stasiun BTET ini menunjukkan bahwa gempa tektonik 10 Juli 2013 mulai mempengaruhi stasiun pantau pada dua jam setelah gempa terjadi.

Hasil uji signifikansi beda dua parameter untuk koordinat interseismic dan satu hari setelah gempa tektonik 10 Juli 2013 terjadi ditunjukkan pada Tabel 3.5 sampai dengan Tabel 3.7. Tabel 3.5 menunjukkan hasil uji pada komponen X, Tabel 3.6 menunjukkan hasil uji pada komponen Y, dan Tabel 3.7 menunjukkan hasil uji pada komponen $\mathrm{Z}$.

Tabel 3.5 Hasil uji signifikansi beda dua parameter komponen X

\begin{tabular}{lccl}
\hline \multicolumn{2}{c}{ Uji Signifikansi Komponen $\mathbf{X}$} & Hasil Uji \\
\cline { 1 - 2 } Stasiun & $\begin{array}{c}\text { Selisih } \\
\text { Koordinat }\end{array}$ & $\begin{array}{c}\text { Nilai t- } \\
\text { hitungan }\end{array}$ & \\
\hline BSAT & 0,01464 & 3,465 & Ditolak \\
BTET & 0,00635 & 1,651 & Diterima \\
SMGY & 0,00466 & 0,848 & Diterima \\
TLLU & 0,00408 & 1,109 & Diterima \\
KTET & 0,00139 & 0,246 & Diterima \\
TIKU & 0,00651 & 1,700 & Diterima \\
LNNG & 0,00186 & 0,451 & Diterima \\
PSKI & 0,00412 & 1,051 & Diterima \\
TRTK & 0,00247 & 0,669 & Diterima \\
MKMK & 0,00116 & 0,328 & Diterima \\
\hline
\end{tabular}

Berdasarkan Tabel 3.5, hasil uji signifikansi beda dua parameter antara koordinat fase interseismic dan koordinat satu hari setelah gempa menunjukkan adanya penolakan $\mathrm{H}_{\mathrm{o}}$ pada stasiun BSAT komponen X. Penolakan $\mathrm{H}_{\mathrm{o}}$ ini mengidentifikasikan bahwa komponen $\mathrm{X}$ pada koordinat BSAT berbeda secara signifikan dengan koordinat fase interseismic setelah satu hari gempa tektonik 10 Juli 2013. Sedangkan untuk stasiun SuGAr yang lain mengalami penerimaan $\mathrm{H}_{\mathrm{o}}$ atau tidak berbeda secara signifikan. 
Tabel 3.6 Hasil uji signifikansi beda dua parameter komponen Y

\begin{tabular}{lccc}
\hline \multicolumn{2}{c}{ Uji Signifikansi Komponen Y } & Hasil Uji \\
\cline { 1 - 3 } Stasiun & $\begin{array}{c}\text { Selisih } \\
\text { Koordinat }\end{array}$ & $\begin{array}{c}\text { Nilai t- } \\
\text { hitungan }\end{array}$ & \\
\hline BSAT & 0,00041 & 0,0393 & Diterima \\
\hline BTET & 0,00085 & 0,0941 & Diterima \\
SMGY & 0,00957 & 0,6583 & Diterima \\
TLLU & 0,00252 & 0,3143 & Diterima \\
KTET & 0,01246 & 0,7881 & Diterima \\
TIKU & 0,01470 & 1,6865 & Diterima \\
LNNG & 0,00244 & 0,2568 & Diterima \\
PSKI & 0,00495 & 0,5434 & Diterima \\
TRTK & 0,00668 & 0,8129 & Diterima \\
MKMK & 0,00870 & 1,2001 & Diterima \\
\hline
\end{tabular}

Pada Tabel 3.6, hasil uji signifikansi beda dua parameter antara komponen Y fase interseismic dan komponen Y satu hari setelah gempa menunjukkan adanya penerimaan $\mathrm{H}_{0}$ pada semua stasiun SuGAr. Hal ini mengidentifikasikan bahwa semua komponen Y pada 10 stasiun SuGAr tidak berbeda secara signifikan setelah satu hari gempa tektonik 10 Juli 2013.

Tabel 3.7 Hasil uji signifikansi beda dua parameter komponen Z

\begin{tabular}{lrrll}
\hline \multicolumn{2}{l}{ Uji Signifikansi Komponen Z } & Hasil Uji \\
\cline { 1 - 3 } Stasiun & $\begin{array}{l}\text { Selisih } \\
\text { Koordinat }\end{array}$ & $\begin{array}{l}\text { Nilai t- } \\
\text { hitungan }\end{array}$ & \\
\hline BSAT & 0,01073 & 4,1041 & Ditolak \\
BTET & 0,00922 & 3,6438 & & Ditolak \\
SMGY & 0,00108 & 0,3098 & & Diterima \\
TLLU & 0,00910 & 3,7598 & Ditolak \\
KTET & 0,01342 & 3,4706 & Ditolak \\
TIKU & 0,00150 & 0,6208 & Diterima \\
LNNG & 0,00295 & 1,1728 & Diterima \\
PSKI & 0,00233 & 0,9202 & Diterima \\
TRTK & 0,00116 & 0,4599 & Diterima \\
MKMK & 0,00263 & 1,1599 & Diterima \\
\hline
\end{tabular}

Berdasarkan Tabel 3.7, hasil uji signifikansi beda dua parameter pada komponen $\mathrm{Z}$ antara koordinat fase interseismic dan koordinat satu hari setelah gempa tektonik menunjukkan adanya penolakan $\mathrm{H}_{\mathrm{o}}$ pada komponen Z stasiun BSAT, TLLU, KTET dan BTET. Penolakan ini mengidentifikasikan adanya perbedaan yang signifikan antara komponen $\mathrm{Z}$ pada fase interseismic dan satu hari setelah gempa tektonik 10 Juli 2013. Sedangkan untuk komponen $\mathrm{Z}$ pada stasiun SuGAr yang lain terjadi penerimaan $\mathrm{H}_{\mathrm{o}}$ yang menunjukkan tidak adanya perbedaan koordinat yang signifikan secara statistik. Adanya perbedaan koordinat pada stasiunstasiun tersebut menunjukkan bahwa setelah dua jam gempa tektonik, koordinat pantau stasiun SuGAr masih terus dipengerahui oleh gempa tersebut.

Selain uji signifikansi beda dua parameter untuk menganalisis perbedaan koordinat fase interseismic dan coseismic, juga dilakukan perbandingan komponen $\mathrm{Z}$ pada koordinat satu jam sebelum dan satu jam setelah gempa tektonik 10 Juli 2013. Perbandingan koordinat ini ditunjukkan pada Tabel 3.8 dan Tabel 3.9.

Tabel 3.8 Perbandingan koordinat komponen $\mathrm{Z}$ pada koordinat satu jam sebelum dan satu jam setelah gempa

\begin{tabular}{lll}
\hline \multirow{2}{*}{ Stasiun } & \multicolumn{2}{c}{ Komponen Z (m) } \\
\cline { 2 - 3 } & $\begin{array}{l}\text { Satu Jam } \\
\text { Sebelum }\end{array}$ & $\begin{array}{l}\text { Satu Jam } \\
\text { Setelah }\end{array}$ \\
\hline BSAT & $-340044,549$ & $-340044,589$ \\
BTET & $-141694,147$ & $-141694,193$ \\
SMGY & $-288996,292$ & $-288996,278$ \\
TLLU & $-199040,100$ & $-199040,089$ \\
KTET & $-261166,095$ & $-261166,051$ \\
TIKU & $-44132,825$ & $-44132,832$ \\
LNNG & $-252634,259$ & $-252634,282$ \\
PSKI & $-124354,026$ & $-124354,072$ \\
TRTK & $-168139,827$ & $-168139,846$ \\
MKMK & $-281063,935$ & $-281063,947$ \\
\hline
\end{tabular}

Tabel 3.9 Perbandingan simpangan baku koordinat komponen $\mathrm{Z}$ pada koordinat satu jam sebelum dan satu jam setelah gempa

\begin{tabular}{|c|c|c|}
\hline \multirow{2}{*}{ Stasiun } & \multicolumn{2}{|c|}{$\begin{array}{c}\text { Simpangan Baku Komponen Z } \\
(\mathrm{cm})\end{array}$} \\
\hline & $\begin{array}{l}\text { Satu Jam } \\
\text { Sebelum }\end{array}$ & $\begin{array}{l}\text { Satu Jam } \\
\text { Setelah }\end{array}$ \\
\hline BSAT & 3,75 & 6,39 \\
\hline BTET & 5,04 & 5,06 \\
\hline SMGY & 6,56 & 10,36 \\
\hline TLLU & 3,36 & 3,74 \\
\hline KTET & 8,17 & 3,84 \\
\hline TIKU & 1,21 & 1,06 \\
\hline LNNG & 1,88 & 3,23 \\
\hline PSKI & 4,91 & 4,22 \\
\hline TRTK & 1,63 & 2,97 \\
\hline MKMK & 3,07 & 3,24 \\
\hline
\end{tabular}

Berdasarkan Tabel 3.8 dan Tabel 3.9, didapatkan bahwa komponen Z stasiun SuGAr pada satu jam sebelum gempa 
memiliki simpangan baku mencapai fraksi centimeter. Sedangkan pada satu jam setelah gempa memiliki simpangan baku hingga 10,36 cm. Hal ini dapat menyebabkan komponen Z stasiun BTET pada satu jam sebelum gempa dan satu jam setelah gempa memiliki perubahan koordinat yang cukup besar, namun belum menunjukkan adanya pengaruh aktivitas tektonik $10 \mathrm{Juli}$ 2013. Perubahan komponen Z pada stasiun BTET sebesar $4,6 \mathrm{~cm}$.

\section{Kesimpulan}

Kesimpulan Kesimpulan yang dapat diambil dari hasil penelitian ini adalah gempa tektonik 10 Juli 2013 yang disebabkan oleh aktivitas tektonik Segmen Mentawai mempengaruhi koordinat stasiun SuGAr setelah dua jam terjadinya gempa. Gempa tektonik mempengaruhi stasiun BTET pada komponen horizontal yaitu komponen Z setelah dua jam terjadinya gempa. Selanjutnya, setelah satu hari terjadinya gempa tektonik, koordinat stasiun SuGAr mengalami perubahan koordinat yang signifikan pada stasiun BSAT komponen X, stasiun BSAT komponen Z, dan stasiun BTET komponen $\mathrm{Z}$.

Pada satu jam sebelum dan satu jam setelah gempa tektonik 10 Juli 2013, komponen Z stasiun BTET memiliki perubahan koordinat sebesar 4,6 cm. Perubahan koordinat ini belum menunjukkan adanya pengaruh aktivitas tektonik 10 Juli 2013. Hal ini dapat disebabkan oleh simpangan baku koordinat hasil pengolahan satu jam sebelum gempa yang mencapai fraksi centimeter, dan simpangan baku koordinat hasil pengolahan satu jam setelah gempa yang mencapai hingga $10,36 \mathrm{~cm}$.

\section{Pernyataan Konflik Kepentingan}

Penulis menyatakan tidak ada konflik kepentingan dalam artikel ini (The authors declare no competing interest).

\section{Referensi}

Bock, L.Y. dan Prawirodirdjo, J.F. 2003. "Crustal Motion in Indonesia from Global Positioning System Measurements". Journal of Geophysical Research, 108(8), 2367.

Earth Observatory of Singapore (EOS). 2012. "Inquiry: Sumatran Earthquakes with GPS", An Istitute of Nanyang Technological University, Earth Science Education.

Fidia, R., Pujiastuti, D., Sabarani, A,Z. 2018. "Korelasi Tingkat Seismisitas dan Periode Ulang Gempa Bumi di Kepulauan Mentawai dengan Menggunakan Metode Guttenberg-Richter". Jurnal Fisika Unand Vol. 7 No. 1. Januari 2018.
Hongbo, T., Chongyang, S., Jin, W., Bin, Z., Jian, W., dan Songbai, X. 2013. "Simulation of Coseismic Effect of Ms.7.0 Lushan Earthquake". Journal of Geodesy and Geodynamics, 4(3), 12-18.

Permana, I., Meilano, I., dan Sarsito, D.A. 2012. "Analisis Deformasi Gempa Padang Tahun 2009 Berdasarkan Data Pengamatan GPS Kontinu Tahun 2009 - 2010". Jurnal Geofisika Vol. 13 No. $2 / 2012$.

Prawirodirjdo. 2000. "Accommodated the Subduction of Indo-Australian Plate through Eurasian Plate."

Sarsito, D.A., Andreas, Abidin, H.Z., Meilano, I., Darmawan, dan Gamal. 2005. "Implikasi Co-Seismic dan PostSeismic Horisontal Displacement Gempa Aceh 2004 terhadap Status Geometrik Data Spasial Wilayah Aceh dan Sekitarnya". Kelompok Keahlian Geodesi, Departemen Teknik Geodesi, Institut Teknologi Bandung. Bandung.

Sugiyanto, D., Zulfakriza, Ismail, N., Adriansyah, R., Meilano, I., Abidin, H.Z. 2011. "Analisis Deformasi Permukaan Patahan Aktif Segmen Seulimumdan Segmen Aceh". Prosiding Seminar Hasil Penelitian Kebencanaan TDMRC-Unsyiah, Banda Aceh, 13 19 April 2011.

Setyonegoro, W., Sunardi, B., Sulastri, Nugraha, J., dan Susilanto, P. 2012. "Analisis Deformasi Gempa Mentawai Tahun 2010 Berdasarkan Data Pengamatan GPS Kontinu Tahun 2010-2011". Jurnal Geofisika Vol. 13 No. 2.

Ulinnuha, H. 2015. "Analisis Deformasi Aspek Geometrik Segmen Mentawai Akibat Gempa Tektonik 10 Juli 2013". Tesis. Program Studi S-2 Teknik Geomatika, Pascasarjana Fakultas Teknik, Universitas Gadjah Mada. Yogyakarta. 